\title{
The Role of Civil Society in Preventing and Countering Sexual Violence in Nigeria
}

\author{
Babayo Sule ${ }^{1}$ and Usman Sambo ${ }^{2}$ \\ ${ }^{1}$ Department of Political Science, Federal University of Kashere, Gombe, Nigeria \\ ${ }^{2}$ Department of Public Administration, Yobe State University Damaturu, Nigeria \\ 'babayosule@gmail.com, ${ }^{2}$ ussambo2@gmail.com
}

\begin{abstract}
Sexual violence is becoming rampant and pervasive in Nigeria particularly in the last years when more incidences are reported. The phenomenon of rape, assault on women, and other types of sexual abuse are currently a social problem in the country and the country's responses and policymaking appear to be ineffective in taming the monster. This study examined specifically the role of Civil Society in the prevention and countering of sexual abuse in Nigeria. The subject matter of sexual abuse has become relevant in contemporary Nigerian society owing to the cultural, economic, political, and social implications of the act. This study gathered data from documented sources and media reports including books, article journals, reports, and internet sources. The data collected were discussed and interpreted using content analysis where big collected data were simplified in themes and sub-themes for an easy illustration. The study discovered that the Civil Society in Nigeria has been active in devising measures and procedures for preventing and countering sexual abuse through collaboration with public officials, relevant international agencies, victims and their families, and other local supporting agencies. The study recommends among several others that the Civil Society should broaden its activities to have integrated religious, traditional, and security institutions in awareness creation for safety measurement, and proactive strategies towards countering and sanctioning the culprits.
\end{abstract}

Keywords: Civil society, Countering, Intervention, Nigeria, Non-governmental organization, Sexual violence

\section{Introduction}

Civil society is an independent and a non-governmental body or movement which operates inter-dependently with the government for civil liberties and responsibilities in the promotion of the overall welfare of the citizenry (Chambers \& Kopstein, 2008 and Edwards, 2011). Civil societies, although, identified with the same nomenclature, differ in their roles and responsibilities. Some of them are purposely meant for the promotion of democracy, some good governance, others prioritize affordable and accessible healthcare delivery services for all especially in the poor countries, many support gender equality, others promote educational development and some specialize in funding and supporting civil liberties and empowerment (Ikelegbe, 2013). Civil societies originated and flourished in Europe as the third tier of government or a body separate from government but which pressurize the government to do

Article history:

Received (April 25, 2021), Review Result (June 1, 2021), Accepted (August 22, 2021) 
the needful. Civil societies emerged in Africa during Africa's quest for democratization and good governance. Recently, Africa re strategized for democratization in the $21^{\text {st }}$ century and one of the basic tenets that accelerate the wheel of democratic rule towards good governance and accountability in civil society (Adejumobi, 2015). As such, civil societies sprang up in Africa from the 1990s to date (Salamon, Anheier, List, Toepler \& Sokolowski, 1997). Civil societies in Africa struggled for the retirement of military regimes in most African countries and spearheaded the process of democratic transition (Sriskandarajah, 2016). Nigeria is one of the countries with the prevalence of civil societies in diverse purposes and aims since the 1990s. In essence, civil societies were recognized as the pillar that mounted incessant pressure on the military to surrender power to the civilian administration in the 1990s (Tar, 2008).

Civil societies act in countering and preventing violence globally.

The violence of any nature is perceived as a threat and exhibition of fear unofficially, against individuals, a group or groups, and states for achieving a particular personal, political, economic, cultural, geographical, and other related goals (Arendt, 1970). It is not only illegal groups that are found to have been involved in the act of violence. Nation-states' internal and external aggressions are also identified as violence (Chomsky, 2013) just in the way that state deliberate deprivation and impoverishment of some section in that society is also a form of violence (Heintze, 2016). Civil societies handled all forms of violence including political, electoral, religious, ethnic, ideological, cultural, and sexual through intervention and prevention (Heintze, 2016; Falola, 1998; Al-Rashed \& Shterin, 2009; Cramer, 2005; De Bruijn \& Van Dijk, 2005; Gentili, 2005; Pottier, Hammond \& Cramer, 2011; Zizek, 2009; Blasko, 2016 and Powell \& Henry, 2017). Among the forms of violence recognized above, sexual violence is the most annoying form that civil societies are keenly interested in tackling because it is an act that is targetted against the vulnerable and weak section of the society that cannot retaliate, protect itself or even pursue justice appropriately (Judge, 2018). Gender-based violence in terms of rape, abuse of women and children, economic deprivation, inequality, child labor, human trafficking, and street hawking all presented different forms of sexual violence across the globe (World Bank Group, 2019). The world is much worried about the recent outburst in rape and different forms of sexual violence against women and children. It is estimated that $35 \%$ of women across the globe experienced either physical or sexual violence. Some national studies revealed that $70 \%$ of women have faced physical or sexual violence (UN Women, 2020). Africa is one of the grey areas of sexual violence as manifested in domestic violence against women, slave labor, women and child trafficking, rape, inequality, and economic deprivation (Barnett, 2004). A study (Muluneh, Stulz, Francis \& Agho, 2020) reported a high alarming rate of sexual violence among African women in recent times. Nigeria is a hotspot of sexual violence in recent times owing to increasing numbers especially in the wake of the COVID 19 pandemic (Reliefweb, 2020).

This study examined the role of civil societies in the countering and prevention of sexual violence in Nigeria owing to the nature in which the phenomenon is taking a new dimension specifically the increasing multiplying numbers in recent times during the COVID 19 lockdown.

\section{Literature review}

The literature review examined critically some pertinent issues that are necessary for the discussion of the subject matter of sexual violence. Central among these issues is the concept of sexual violence, nature and dimension of sexual violence in Nigeria, causes of sexual 
violence in Nigeria, manifestations of sexual violence in Nigeria, effects of sexual violence in Nigeria, and the overview of civil societies in Nigeria.

\subsection{The concept of sexual violence}

Sexual violence is a criminal offense that roars up in the mind, translates into thought and action. It involves the evil intention and action of sexual sadists, sexual slavery, serial killers, revenge murderers, and a complete killer (Hazelwood \& Michaud, 2018). Sexual violence is a criminal offense against humanity, a conflict-related assault, and terror-bound intimidation against the vulnerable. Oftentimes, armed group violence subjected non-combatants to different forms of violence including sexual assaults such as rape, sexual slavery, and forced marriage (Bigio \& Vogelstein, 2017). Sexual violence, synonymously interchanged with Gender-Based Violence (GBV), is any inimical action that is assaulted against a person's volition and which is based on socially configured sex differentiation between men and women. GBV affects both males and females but the female gender is the most affected because of gender inequalities (The World Bank, 2019). Sexual violence is any non-voluntary sexual assault, threat, fear, or an attempt to perpetrate or compel somebody to perform an act against his will sexually. These acts are considered as violence when use of force, violence, threat, and coercion are used (African Union, 2017). Sexual violence is a criminal habit attached with psychological in-built mechanisms for psychiatric imbalance towards suffering humanity. This attitude can be countered using psychoanalysis of the criminals (Tosh, 2015).

Sexual violence is sometimes interpreted as rape but it is beyond that. It also consists of assault, sexual harassment, child sexual abuse, slavery, and underage labor (Freedman, 2013). Hayes (2014) further added that sometimes sexual violence can be performed within legality. For instance, domestic violence perpetrated against married women by their husbands is a good example. They are being raped, molested, tortured, engaged in forced labor, and mutilation. Sexual violence occurs everywhere in the world and it has an influential impact on the physical and mental health of the victim. Sexual reproductive difficulties, suicide, stereotyping and mortal diseases such as HIV may result from the incidence. Sexual violence includes rape within marriage, rape by strangers, rape during armed conflict, unwanted sex harassment, sexual abuse of children, forced marriage or cohabitation, forced abortion, denial of the usage of contraception, child trafficking, gang rape, violence from an intimate partner, violent acts against women and forced prostitution (WHO, 2014). Sexual violence is not only occurring for women or female gender only. Evidence reported thousands of cases against men especially during war and conflicts (Feron, 2017). The way sexual violence is perpetrated from men to men, so also it is occurring between woman to woman. The societal concept of homophobia, biphobia, and transphobia all culminated in the emergence of lesbian groups that sometimes assaulted their fellow female gender by force. In this regard, does she call it rape or what? Certainly, it is sexual violence (Girshick, 2002).

The sexual violence phenomenon was not given the proper attention that it deserves until the late 19th century because of the politicization of the issue. It was practically downplayed as just a feminist political movement (Harrington, 2010). It was a recent interest by media in childhood sexual abuse perpetrated by institutions, and celebrities that promoted awareness on sexual violence and its attendant consequences (Healicon, 2015). After the mass rape in Bosnia and Uganda, sexual violence earned the securitization status when it was elevated to the level of global security concern (Hischauer, 2014). Violence against women is a pervasive phenomenon in contemporary society and responding towards the incidence is difficult. This is due to constant challenges in social work, health, and related professions (Lombard \& 
McMillan, 2013). Sexual violence is protected using several strategies such as taking action and generating evidence (World Health Organisation, 2010), using interdisciplinary approaches to overcome a rape culture (Powell et al. 2014), evidence-based policy and prevention (Jeglic $\&$ Calkins, 2016), the use of spirituality and religion for healing and recovery (Dale \& Daniel, 2011), coping with the consequences of the violence (Kelly, 1988) and impact of litigation to sanction the culprits and deter future occurrences (Muwanga, Traore, Chekir \& Tsunga, 2016).

Women face various types of abuse from their intimate partners as configured into physical assault, sexual violence, threats of physical or sexual violence, and psychological/emotional violence (Frieze et al. 2020). Frieze et al. (2020) observed that men abuse their partners emanating from three (3) major factors consisting of personality and family background, stress, and violence as an expression of masculinity. Additionally, Frieze et al. (2020) further submitted that some women that were abused develop some coping strategies in the posttraumatic stage among which include taking action against future occurrence, withdrawal from society for a while, reaching out to others for help, and alcohol or drug abuse. The study by Frieze et al. (2020) is a comprehensive summary of Gender-Based Violence in all ramifications except that the assumption of violence as an expression of masculinity is contemporarily becoming difficult to establish due to the increasing role of civil societies in women empowerment. The customary system is the usual procedure in which Gender-Based Violence is addressed in many societies, particularly in Africa. Civil societies intervene in this respect by pushing and supporting women to participate in the democratic process (Britton, 2020). However, the level of women's participation in African politics is still a long way to go. However, Bates \& Taylor (2019), see Gender-Based Violence as the common expression of men's privilege and power. In the study, Bates \& Taylor (2019) expressed optimism that there is a changing narrative to the research on GBV and the responses owing to increased attention paid by civil societies and women movements across the world who identified the phenomenon as an act of inequality. This position by Bates \& Taylor (2019) corroborates that of Frieze et al. (2020) of an expression of masculinity even though, this study finds it difficult to accept such assumption.

Javier \& Herron (2018) believed that GBV is still continuous despite several counterstrategies adopted by many governments and civil societies across the world. Since according to them, the remedies remain elusive, an exploration into the subject of study is necessary. This study agreed with this emphasis. Snyder (2019) presents an interesting view when she argues that there is substantial damage caused by GBV that escaped our attention but may kill the victims. Some severe injuries can be sustained without physical bruises but can be inimical enough to permanently inflict a crippling injury to the recipient of the brutal act. Thus, what Snyder (2019) did here is to successfully draw the attention of the audience to the extreme effects of GBV that we are not in most cases paying attention to. In another approach, Goodmark (2018) instead of limiting the analysis of GBV to internal dangerous bruises expanded that it is an all-encompassing phenomenon that affects the society squarely in the criminal justice delivery, economic problem, public health problem, and human rights issue. Hattery \& Smith (2019) believed that civil societies are instrumental in responding to GBV in many ways by incorporating institutions and entertainment bodies such as fraternities, military, prison sentences, sports world, religious organizations including churches and mosques, and film industries.

Thus, summarising from the above, this study identifies that sexual violence is any unwanted sexual advance perpetrated forcefully in a peaceful or war environment, by a sexual intimate person such as a husband, a stranger, or a gang, and by either opposite sex or the same sex belonging, to which it resulted in health, mental and physical challenges for the victims. 
However, this study found that male sexual assault or advancement against women is higher and as such, the term sexual violence and the subject of study will focus on sexual violence from men against the female gender or gender-based violence (GBV) in Nigeria which is the area of study.

\subsection{Nature and dimension of sexual violence in Nigeria}

Sexual violence or Gender-Based Violence in Nigeria is exploding continuously like a bushfire in recent times (Eze, 2013). The phenomenon has taken a new dimension. In some years back, cases of molestation and sexual abuse in Africa are reported for women of any age from puberty and above in most of the cases. Contemporarily, the raping of minors is giving the scenario a new ugly face (Muluneh et al. 2020). In Nigeria, domestic violence is being reported for several decades where intimate and sexual suffered severe assault, bruises, disfiguring, molestation, abuse, and maltreatment by their partners. This is not categorized as rape but is a part of sexual violence (Taft \& Blyth, 2016). Rape is being reported from all parts of the country consisting of a single perpetrator, gang rape, raping by burglars, armed robbers, and sexual criminals (Esere, Idowu, Durusaro \& Omotosho, 2009). In places of work, there are serious cases of sexual harassment by superior officers against their subordinates for sexual advancement in which refusal cost the affected person his/her job, promotion, or other privileges and a witch-hunting (Akin-Odanye, 2018). In schools, especially, tertiary institutions, students are sexually harassed by immoral lecturers who demand sex for marks (Margaret-Mary, Mezie-Okoye \& Alamina, 2014 and Raphael, Ajah \& Chukwuemeka, 2019). The 2019 BBC report of investigative journalism in Ghana and Nigeria disclosed the extent of the sexual abuse by teachers against their students. This has been undertaken with the support of the civil societies in the two (2) countries of study (Muluneh et al. 2020). Minors are lured by criminals and raped using inducement while in other cases, they are being coerced into it through the use of threat. The issue with sexual violence in Nigeria is that most of the cases are either uninvestigated or unreported (Chiazor, Ozoya, Udume \& Egharevba, 2016). The families of the victims felt ashamed of reporting the incident to the appropriate authorities for fear of stereotyping, social stigma, and the future of the victim especially if it is a minor. This way, the civil societies, authorities, and other legal aspects of the issue are skipped which made justice difficult (United Nations Nigeria, 2020). In other cases, the culprits are apprehended and subjected before the law but the chameleon-like style of the Nigerian judicial system when a privileged person is involved discouraged the civil societies and activists from pursuing the cases to their logical conclusion in addition to lack of cooperation from the families of the victims. There are several cases of injuries and health issues such as HIV/AIDS infection, incessant bleeding, psychological trauma, fear, stigma, VVF, and family crisis (Amnesty International, 2017).

\subsection{Causes of sexual violence in Nigeria}

Several drivers are believed to have catapulted sexual violence in Nigeria. Culture is one of them. In most of the cultures of Nigerian societies, patriarchy is given an ultimate priority over matriarchy and that has succeeded in denigrating the status of women in the society. Religion is another attribute. Besides, culturally, the fear of stigmatization compelled many families to keep the incidences confidential which shields the criminals and encourages them to perpetrate their crimes. Some followers of religions like Christianity and Islam misperceived the teaching of their religion towards women and their relationship portray as a master-slave relationship (Kemisola \& Olawale, 2017). Globalization and external culture contribute to escalating the 
rape culture and sexual violence in Nigeria. The spread of media especially television, the internet, and social media influenced many youths sexually because of watching pornography and violent sexual films. They tend to imitate the same scene that they watched in movies practically. The mode of dressing of some female sex is another driver (Margaret-Mary et al. 2014). The way and manner in which they appear with tantalizing and alluring dresses in the public sphere lured criminals towards exhibiting sexual assault on them. Additionally, criminal tendencies and sexual masochists are sometimes individuals with a natural in-built mechanism for sexual sadism and such persons exist in any society including Nigeria (Amnesty International, 2017). Economic condition, social status, and vulnerability are other factors that propelled sexual violence. The majority of Nigerians live in poverty, deprivation, destitution, and impoverishment. They live in slums where security is minimal and where it is easier to perpetrate a crime and escape freely. Additionally, the inability of the justice system to extend a punitive measure against the criminals provides a breeding ground for rapists and sexual assaulters to continue with their evil actions (Muluneh et al. 2020).

\subsection{Manifestations of sexual violence in Nigeria}

The global figures on rape and sexual violence are alarming and unanimously call for collective action. It is estimated that $35 \%$ of women worldwide have experienced sexual violence in their lives. It is reported that about 87, 000 women were killed in 2017 resulting from sexual violence. Africa has the highest incidence of sexual violence in the world accounting for $34.4 \%$ of the total global victims in 2014. In the same year, it was reported that about $60 \%$ of child trafficking in Africa emanated from Nigeria. About $30 \%$ of Nigerian women experienced sexual and domestic violence (Women at Risk International Foundation, WARIF 2020). Adult women accounted for about $50 \%$ of the total global human trafficking, 12 million under 18 girls are married each year in Sub-Saharan Africa and there is a total of 650 million under 18 married women worldwide. At least 200 million women and girls underwent female genital mutilation aged 15-49 with prevalence in most African countries especially in Nigeria. Approximately, 15 million adolescent girls aged 15-19 experienced forced sex, 23\% of female undergraduate universities' students worldwide reported sexual advancement or assault by either their teachers or male colleagues (UN Women, 2020). In another report, globally, one in four girls experienced sexual violence, one in ten boys before the age of $18,88 \%$ of sexual abuse victims know the abuser, only $4.2 \%$ of girls and $3.4 \%$ of boys received help and out of every seven (7), sexual abuse occurs in the afternoon (The Cece Yara Foundation, 2020).

In Nigeria, women faced societal deprivation which is another form of sexual violence adopted and agreed in this study. Incidence of rape indicates a case of 1 per 10 especially in the Southern part of the country where the case is more pronounced and prevalent (Abioye, 2019). In 2017, 2, 279 cases of rape and assault were reported, 1, 164 cases of unnatural or anal sex, 0 convictions reported by police, and only 1 state out of 36 reported no case (Orjinmo, 2020). A report by UN Women (2020) further discloses that $17.4 \%$ of Nigerian women experienced lifetime physical or intimate sexual partner violence, $11 \%$ share the same experience in the last twelve months (January to December 2019), 1.5\% experienced lifetime non-partner sexual violence, child marriage $43.5 \%$ and female genital mutilation $18.4 \%$. The NOI Polls in July 2019 revealed that about $85 \%$ of Nigerians believed that there is a high prevalence of rape in Nigeria with 3 in every 10 Nigerians disclosing that they know somebody who was raped. Rape and other sexual abuses are considered as one of the major concerns in the 16 out of 24 IDPs' camps in Maiduguri. About 33\% of the respondents believed that the offenders escaped justice (Relief Web, 2020). The Minister of Women Affairs and Social Development in 2019 stressed 
that about 2 million Nigerians are raped every year and underreporting is the major obstacle since not more than 50, 000 were reported in 2019 (Adebajo, 2019). From January to May 2020, about 717 cases of rape were recorded and 631 cases were investigated and charged to court (Mutua, 2020). COVID 19 is attributed to the surge in the incidences of sexual violence. Although, state of emergency was declared in the country on rape and sexual assault, only 17 states so far signed the law into force (Isiaka, 2020). The Minister of Women Affairs in Nigeria reported that about 3, 600 cases of rape were recorded during the lockdown as a result of the COVID 19 pandemic (Iroanusi, 2020). One vital aspect that reports and studies on sexual violence are neglecting and which should be considered is the under 18 voluntary pregnancies. While child marriage and under 18 sexual assaults are frowned at, the number of unwanted outof-wedlock pregnancies involving under 18 is increasing and the activists and laws are not paying attention to that.

\subsection{Effects of sexual violence}

Sexual violence has several lifetime implications on the victims and the perpetrators as well as the government. For instance, most of the assaulted girls and women faced psychological trauma of various magnitudes, contacted infectious diseases such as sexually transmitted diseases, HIV/AIDS, fertility issues in a later stage of life because of damage in the womb, VVF, stigma, internal agony of knowing that the perpetrators are unpunished, lack of confidence in the justice system and cynicism of the society (Judge, 2018). From the part of the culprits, reputation is damaged, stigmatization, risk of facing prison sentences with heavy punishment, desertion by family members, and possible illegal reproduction of mankind through an accidental impregnating of the victim which haunts the offender. On the part of the government, it is reported that sexual violence cost the country billions of Naira which further shrank the GDP in 2019 and 2020. From the perspective of family settings, sexual violence and abuses lead to marriage dissolution, broken homes, and wandering children in the streets (UN Women, 2020). Sexual violence in essence has effects that affect all members of society. The problem should be approached from a collective perspective because its repercussions have collateral damage on all stakeholders in society. Children are born out of the proceeds of the illegal criminal act without knowing their fault but they faced social stigmatization and enduring lifetime isolation from the crime that they know not (Muluneh et al. 2020).

\subsection{Overview of civil societies in Nigeria}

Civil society is non-governmental, non-profit, and social services engagement associations and groups that pursue various targets in the state depending on the mission and aim of the movement (Almond \& Verba, 1963). Civil society equalizes and synthesizes interaction between individuals and states in a democratic setting (Adibe, 2015). Civil society, in general, promotes democracy, good governance, and human rights within the ambit of legality that is usually accommodated by the states (Bratton, 1994). This consists of Civil Society Organisations (CSOs), Non-Governmental Organisations (NGOs), Community Based Organisations (CBOs), Faith-Based Organisations (FBOs), Trade Unions, Farmers Association, Academics, Professional Organisations, Students Movements and other activities which are not related to political organizations (Edwards, 2011). The resurgence of global democratization made civil society concepts and ideas vital (Emodia \& Erunke, 2007). In contemporary times, the role of civil societies across the globe is changing most especially in tackling societal challenges. Civil society is now an evolving phenomenon, being increasingly proactive in its response towards remedying societal challenges such as gender inequality, 
sexual violence, poverty, school enrolment, health care services delivery, and several others (Salamon et al. 1997). In Africa, civil societies existed or emerged actively since the 1990s but, did not function well owing to the dictatorial activities of African leaders (Ehrenberg, 2011). The main cause of the weakness of civil societies in Africa is because the state subverts the growth of civil societies. In Sub-Saharan Africa, states are weak and there is a high tendency for political instability (United States Agency for International Development, 2006). The history and emergence of civil societies in Nigeria can be categorized into four basic stages: pre-colonial period, colonial period, military era, and post-military period (Udogu, 1995). Nigeria has for long enjoyed a vibrant civil society that takes the shape of activists, associations, and other professional unions. Civil societies play an important role in sustaining development politically, economically, socially, and in other aspects (Utsaha, 2014). Civil societies in Nigeria play the role of good governance, infrastructure provision, economic empowerment projects, social services, human capital development, poverty alleviation, relief, and humanitarian services, and conflict management (Ikelegbe, 2013).

\section{Theoretical framework}

This work adopted a retinue of theories succinctly examined but adequately explained in their contents and contexts towards application in the subject matter of study. The Theory of Civil Society as a Third Tier of Government is analyzed, Routine Activity Theory of Crime and a Sociological-Psychological group of theories such as Biological Theory, Psychodynamic Theory, Behavioural Theory, Attachment Theory Cognitive-Behavioural Theory, Integrated Theory and Theories on Abuse by Clergy.

The Theory of Civil Society as a Third Tier of Government was sponsored and promoted by the Kettering Foundation in 1987 in the United States of America. The Kettering Foundation financed the study and investigation of civil societies across institutions and research centers. Many universities in the US benefitted from the program. For instance, the University of Pennsylvania declared in 1996 that it has opened a center for the study of civil societies. The University of Chicago too in 1997 announced the establishment of the center for research on civil societies under the mentorship of Salamon and Anheier (Sriskandarajah, 2016). The theory assumes that civil society is a complement of the government business and private sector which made it the third tier in the process of running the affairs of the state. Since the government is separate, private organizations are independent, and civil society is neither a government nor for-profit purpose as in the private sector, it is a third sector in the state. The theory further assumes that society is not a product of only political order but it is also a function of the social order where social groups operate voluntarily in achieving their goals (Sriskandarajah, 2016). The theory is relevant in the study of this nature because of its plausible, feasible, and unambiguous explanation of civil societies as a body or organization that is free from government and private establishment which qualifies its activity as specific. The theory has its weakness in emphasizing that civil societies play a social role more than political. Most civil societies across the world, in African and in Nigeria play the role of political function than social ones. Civil societies that operate in the social sphere such as the promotion of girl-child, human rights, the campaign against sexual violence, better life, and healthcare services are all social civil societies that operate in Nigeria as assumed by this theory.

The Routine Activity Theory was advanced by Cohen and Felson (1979) cited in Bottom and Wiles, 1997:320). The theory assumes that crime is possible and flourishes because of the existence of three factors: the criminals, the subject of the crime or victim, and the absence of a coercive enforcement body that can sanction the criminals. The theory further agrees that for 
a crime to occur, there must be the presence of the above three elements. Furthermore, the theory suggests that criminals routinely check for their targets to ensure that they can perpetuate their crimes undetected, unpunished, and uninterrupted. The theory is a logical exploration of the context of this study because the sexual assault in Nigeria is rising continuously most especially during the outbreak of COVID 19 and lockdown because the criminals hiding under the umbrella of travel and movement ban to conduct their criminal activities undetected. In a situation where the criminals are found, the level and nature of the report are extremely low as reported above that only $33 \%$ of the cases are reported. To this end, the criminals are certain that they could escape the wrath of the law either through social setting, culture, or weak legal enforcement as proposed by the theory.

Additionally, Gannon \& Ciardha (2012), presented some galaxies of psychological theories of sexual abuse as espoused below. The first theory is Biological Theory which is concerned with the organic explanation of human behavior and physiological factors which influence hormone levels and chromosomal makeup which in return affect sexual behavior leading to sexuality, aggression, cognition, emotion, and personality. Psychodynamic Theory is sexual deviance which is an expression of unresolved problems that are experienced during the stages of development. Sexual deviant behavior occurs when the three elements of the human psyche, id, ego, and superego could not balance and the id became overactive leading to sexual assault. The Behavioural Theory expresses that sexual deviant behavior is a learned condition acquired through which conventional sexuality is learned but became abusive when basic conditioning principles are discarded. The Attachment Theory proposes that human have a propensity to establish a strong emotional bond with others and when the intimate ones are loss or the relationship break, emotional distress persuade them to act weird as a result of their isolation and loneliness. In terms of Cognitive-Behavioural Theory, the thoughts of offenders are found to have affected their behavior because the offenders or criminals diminish and downplay the magnitude of their crime through excuses, unjustified defenses, and rationality. The Integrated Theory presumes that there are preconditions to child sexual abuse. This position integrates the various theories or approaches to explain deviant sexual behavior. Finally, the Theory on Abuse by Clergy tries to explore why some priests molest children sexually and why others do not. The most feasible explanation advanced is the level of sexual development of the priests. Some are possessing high sexual libido while others are experiencing stunted sexual growth courtesy of celibacy and exemption. All these groups of psychological theories are relevant in the context of this study because one cannot debunk the possibility of influential behavior, psychological condition, and sexual development in the psyche of the offenders. One major mortal blow for this group of theories is the total negligence of the environment. Apart from psychology, one important factor that influences behavior and attitudes is the inhabitants' environment.

\section{Method of data collection and analysis}

The study gathered data from secondary sources because it is a qualitative descriptiveanalytical approach. Existing documented sources such as books, journal articles, reports, internet sources, and media reports were consulted for the data collection. This is justified because the area of study, Nigeria is difficult or practically impossible to be covered by the researchers due to financial, time, procedural, and limitations in data collection. The data collected were discussed and interpreted using content analysis to subject the findings to the rigors of academic dexterity. The major limitation encountered in the process of writing the research report is accessibility to data owing to irregular internet services, time constraints consequent from tight working schedules. However, the data collection and analysis were 
successful despite challenges because the use of secondary data minimized financial demands and conflict of interest.

\section{Discussions and findings}

This section discussed the major issues raised in the study specifically it has linked up the study with the role of civil societies in their efforts towards countering and preventing the spread of sexual violence in Nigeria.

\subsection{Civil societies and counter sexual violence in Nigeria}

There are numerous civil societies both locally and internationally which are operating in Nigeria towards countering sexual violence. Although, the overall aim is not just preventing and countering sexual violence. The organizations are promoting girl-child education, human rights, child right, and social justice. The international civil societies such as United Nations Women (UN Women), United Nations Children and Education Fund (UNICEF), United States Agency for International Development (USAID), World Health Organisation (WHO), Amnesty International, Human Rights Watch, Save the Children, Action Against Hunger, MAMAYE, Action Aid, United Nations Development Project (UNDP), United Nations (UN), Economic Community for the West African States (ECOWAS), European Union (EU) and African Union (AU). These international donors or civil societies collaborate with hundreds of local Non-Governmental Organisations (NGOs) through the supply of funds for the execution of projects, training, logistics, and internship (Mutua, 2020). They provide varieties of activities that promote freedom, liberty, and gender equality. They emphasize recently countering and preventing sexual violence and domestic violence against women or GBV. In the process, they provide millions of USD to support various policies, programs, and activities towards achieving their goals. They also collaborate with the policymakers in Nigeria to fashion out policies and programs that will prevent sexual violence and in the case of reported incidences, how to support the victims and punish the culprits through the process of law (Iroanusi, 2020). Some of the services or activities that the above-mentioned civil societies provided towards countering and preventing the spread of sexual violence in Nigeria include the following:

(1) Advocacy: one of the ways that civil societies participate and contribute in countering and preventing sexual violence in Nigeria is advocacy. There are several programs and activities that these agencies and organizations sponsored in Nigeria especially from 2014 when the incidences of rape, domestic violence, and other forms of sexual assaults became the subject of a daily report. The likes of UN Women, for example, sponsored a radio program titled "Zamu Iya" in some selected radio stations in all the six geopolitical zones and Federal Capital Territory Abuja (FCTA) worth millions of USDs (UN Women, 2020). The Save the Children and Action Against Hunger also followed suit by sponsoring physical lectures, gatherings, rallies, and radio programs especially in the Northern part of the country where the incidences of girl-child education and female gender enrolment in schools, early marriage, and genital mutilation are reported more than other parts of the country (Judge, 2018).

(2) Intervention: the civil societies intervened in various cases of domestic violence and sexual violence across the country to pursue justice for the victims, provide succor for relieving them against psychological trauma and social stigmatization. For instance, Amnesty International 2017 reported that it had intervened in over 300 cases of rape, assault, sexual abuse, and sexual violence against female gender across the country (Amnesty International, 2017). The Human Rights Watch reported that it has been monitoring and unveiling cases of rape in the country from 2014 to 2020 in which over 6, 000 reported cases were followed up 
for justice (Delay, 2019). Other civil societies such as MAMAYE, UN Women, Action Aid, Action Against Hunger, WHO, UNDP, USAID, and UNICEF all are reported to have provided shelter for victims of sexual abuse, intervened in the mediation of domestic sexual abuse by intimate partners or marital partners, provision of materials such as cloth, food items, and medicine for the victims in addition to health medical bills expenses covered by the organizations (Orjinmo, 2020). In some cases, the victims are enrolled and sponsored financially to pursue further education up to the higher stage of learning. All these are reported to have cost the organizations millions of US Dollars and Euros, converted into billions of Naira (Muluneh et al. 2020).

(3) Collaboration: the international civil societies that are mentioned in this study also participate in the process of countering and preventing sexual violence through a collaboration with local civil societies. There are hundreds of civil societies spread across the country in pursuance of different goals. The donors selected those that are found to have been involved in the activism of promoting gender equality and girl child right. They collaborate with them through a partnership where the international civil societies provide funding, training, sponsorship of programs, and physical activities towards enlightening the society on the evil act of sexual abuse and the measures of responding if the victim is found to be helpless (Isiaka, 2020). The UN Women and MAMAYE reported that through collaboration with local civil societies, several hundred attempted cases of rape were averted, hundreds were reported and many cases were addressed in the competent court of law where the culprits are sentenced accordingly while the victims are taken care of through a special support program (UN Women, 2020).

(4) Action: the civil societies collaborated in taking an action against the cases of sexual violence. One of the ways is proactive measures where data are assembled annually by the likes of UN Women, Action Aid, USAID, UNDP, EU, AU, and several other organizations. The data determined the direction of reporting, action, and plan towards prevention. For instance, the NOI Polls conducted in collaboration with some of these organizations disclosed that only $33 \%$ of rape cases are officially reported (Relief Web, 2020). These gathered data enabled for an action where the organizations felt that they need to actively involve themselves in the process to support and motivate the victims to feel free in reporting their confirmed cases from where organizations like Human Rights Watch and Amnesty International will intervene and pursue justice accordingly.

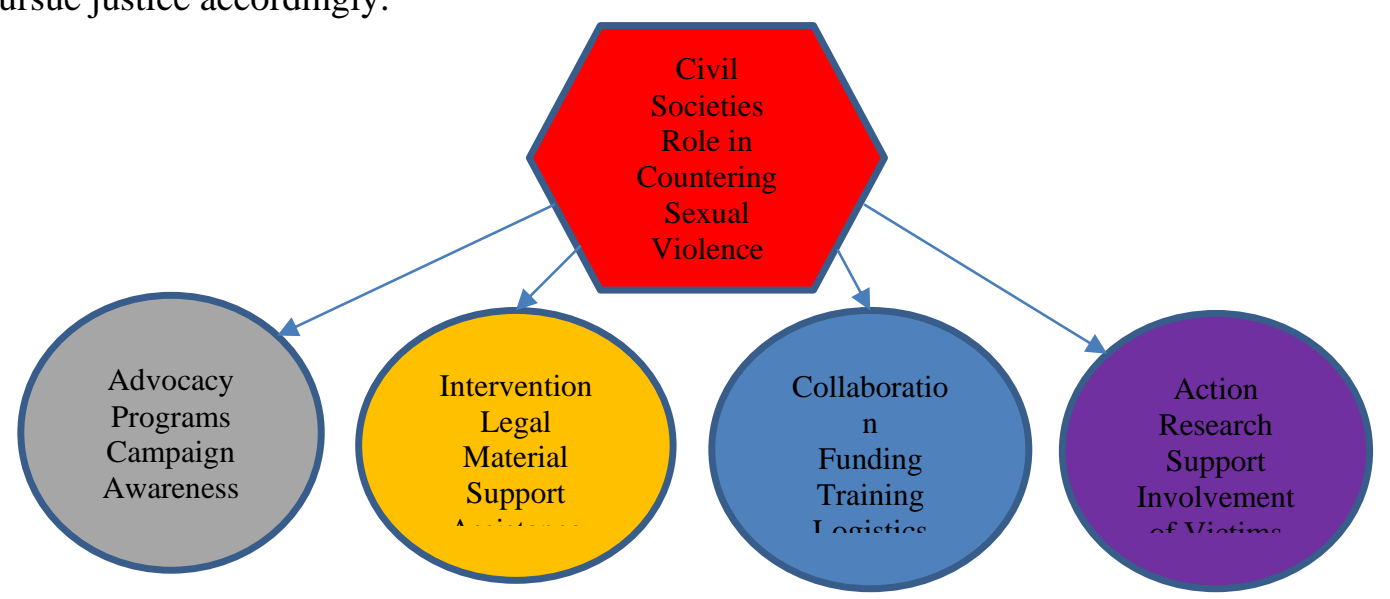

Source: Designed by the Authors 2020

Figure 1. Model showing the role of civil societies in the prevention and countering of sexual Violence in Nigeria 


\section{Conclusion and recommendations}

The paper concludes that sexual violence is now a global phenomenon with a collective global concern for international actors. The incidences keep on rising globally but the African cases proved to be alarming where the surge in the incidences led to the total percentage of nearly 40 of the total global cases. The rampant cases of sexual violence are found to have been reported more in Sub-Saharan Africa. Nigeria is one of the Sub-Saharan African countries where the cases of rape became unbearable and terrifying with the Minister of Women Affairs having being reported to have said that about 2 million women are raped yearly in the country. The paper also reported that sexual violence does not imply only the aggression of men over women as most of the studies tend to portray. Sexual assault or advancement occurs among women and men alike, especially in conflict zones. The study also concluded that states' discrimination against the female gender is another form of sexual violence because it impoverished them and subjected them to a life of destitution where they became easy prey for violent attacks by the criminals. The cases of rape became more pronounced during the COVID 19 lockdown which indicates that many men became frustrated due to the economic meltdown transferring their aggression against the weak and vulnerable ones. The study found that civil societies are instrumental in their quest for the prevention and countering of sexual violence. Several international civil societies collaborated with domestic ones in activities of advocacy, intervention, collaboration, and action. However, the study identified that there are some loopholes that the civil societies are not utilizing adequately and which are denying them from achieving their goals. Some of the following recommendations suffix for remedying the gap: religious clerics should be adequately consulted and implored to participate in the process because of the public trust in them; royal fathers should be engaged in attending to domestic issues of sexual violence in collaboration with the civil societies; the cases of under 18 voluntary out of wedlock pregnancy should also be discouraged otherwise it may continue to motivate early sex and unwanted pregnancies which will lead to more out of school children from the female gender; the legal procedure of handling the cases of sexual violence should be upgraded to be precise, easily pursued and comprehensive in addressing the plight of the victims; other states that are foot-dragging in the implementation of the laws against sexual violence should be pressurized by the civil societies to adopt them immediately and severe punishment should be introduced to deter such criminal behavior.

\section{References}

[1] O. Abioye, "For Nigeria's women, the threat of sexual violence is never far away," Fair Observer, Retrieved from https://www.fairobserver.com/culture/nigeria-sexual-violence-arewa-me-too-movement-africa-news88876/ on 11-08-2020 at 7:19 pm, (2020)

[2] K. Adebajo, "Fact check: Are 2 million Nigerians raped every year? Here is what we know," International Centre for Investigative Reporting, Retrieved from https://www.icirnigeria.org/fact-check-are-2-millionnigerians-raped-every-year/ on 11-08-2020 at 7:36 pm, (2019)

[3] S. Adejumobi, "Democratic performance in Africa: Progress, faltering hopes," in Adejumobi, S. (Ed.) National Democratic Reforms in Africa: Changes and Challenges, New York: Palgrave Macmillan, pp.1-22, (2015)

[4] J. Adibe, "The 2015 presidential election in Nigeria: The issues and challenges," Washington, USA: Brookings Institution, (2015)

[5] African Union, "Guidelines on combating sexual violence and its consequences in Africa," Addis Ababa, Ethiopia: African Union, (2017)

[6] E. O. Akin-Odanye, "Prevalence and management of child sexual abuse cases presented at Nigerian hospitals: A systematic review," Journal of Health and Social Sciences, vol.3, no.2, pp.109-124, (2018) 
[7] G. Almond and S. Verba, "The civic culture: Political attitudes and democracy in five nations," Princeton, USA: Princeton University Press, (1963)

[8] M. Al-Rasheed and M. Shterin, "Introduction: Between death for faith and dying for the faith, reflections on religion, politics, society, and violence,” In Al-Rasheed, M., \& Shterin, M. (Eds.), Dying for Faith: Religiously Motivated Violence in Contemporary World, New York, USA: Palgrave Macmillan, pp.1-3, (2009)

[9] Amnesty International, "Nigeria: Submission to the United Nations committee on the elimination of discrimination against women, (2017), Retrieved from amnesty.org.ng on 11-08-2020 at 4:43 pm

[10] H. Arendt, "On violence, San Diego," USA: Harcourt Brace Jovanovich Publishers, (1970)

[11] P. A. Barnett, "Dangerous desire: Literature of sexual freedom and sexual violence since the sixties," New York, USA: Routledge, (2004)

[12] E. A. Bates and J. C. Taylor, "Introduction: Why change current practice?” In Bates, E.A., \& Taylor, J.C. (Eds.), Intimate Partner Violence: New Perspectives in Research and Practice, London: Routledge, Taylor \& Francis, pp.1-8, (2019)

[13] J. Bigio and R. Vogelstein, "Countering sexual violence in conflict," New York, USA: Council on Foreign Relations, (2017)

[14] B. L. Blasko, “Overview of sexual offender typologies, recidivism, and treatment,” In Jeglic, E.L. \& Calkins, C. (Eds.) Sexual Violence: Evidence-Based Policy and Prevention, pp.11-32. Geneva, Switzerland: Springer, Bottom, A.E., \& Wiles, P. (1997)

[15] "Environmental Criminology" in Maguire, M., Moran, R., \& Reiner, R. (Eds.), The Oxford Handbook of Criminology, pp.650-656). London, UK: Oxford University Press, (2016)

[16] M. Bratton, "Civil society and political transition in Africa," Boston: Institute for Development Research, (1994)

[17] H. E. Britton, "Ending gender-based violence: Justice and community in South Africa," Illinois: University of Illinois Press, (2020)

[18] S. Chambers and J. Kopstein, "Civil society and the state," In Phillips, A., Honig, B., \& Dryzek, J.S. (Eds.), The Oxford Handbook of Political Theory, pp.364-381. Toronto, Canada: Oxford, (2008)

[19] I. A. Chiazor, M. I. Ozoya, M. Udume, and M. E. Egharevba, "Taming the rape scourge in Nigeria: Issues and actions," Gender and Behaviour, vol.14. no.3, pp.7764-7785, (2016)

[20] N. Chomsky, “On Anarchism,” New York, USA: The New Press, (2013)

[21] C. Cramer, “Angola and the theory of war," In Chabal, P. Engel, U. \& Gentili, E. (Eds.) Theories of Conflict And Approaches to Conflict Prevention, Boston, USA: Brill, pp.17-34, (2005)

[22] S. Dale and J. H. Daniel, "Spirituality/religion as a healing pathway for survivors of sexual violence," In BryantDavis, T. (Ed.), Surviving Sexual Violence, pp.318-327 Lanham, USA: Rowman \& Littlefield Publishers, (2011)

[23] M. De Bruijn and H. Van Dijk, "Natural resources, scarcity, and conflict: A perspective from below," In Chabal, P., Engel, U., \& Gentili, E. (Eds.), Theories of Conflict And Approaches to Conflict Prevention, Boston, USA: Brill, pp.55-74, (2005)

[24] J. Delay, "Nigeria: Widespread violence ushers in president's new term investigate attacks, ensure justice," Abuja, Nigeria: Human Rights Watch, (2019)

[25] M. Edwards, "The Oxford handbook of civil society, New York, USA: Oxford University, (2011)

[26] J. Ehrenberg, "The history of civil society ideas," In Edwards, M. (Ed.), The Oxford Handbook of Civil Society, New York: Oxford University Press, pp.15-28, (2011)

[27] S. M. Emodia and C. E. Erunke, "Civil society and democratic consolidation in Nigeria's fourth republic: An appraisal,” Pakistan Journal of Social Sciences, vol.4, no.5, pp.672-676, (2007)

[28] M. O. Esere, A. I. Idowu, A. I. Durusaro, and J. O. Omotosho, "Causes and consequences of intimate partner rape and violence: Experiences of victims in Lagos, Nigeria," Journal of AIDS and HIV Research, vol.1, no.1, pp.1-7, (2009)

[29] U. O. Eze, "Prevention of sexual assault in Nigeria," Annals of Ibadan Postgraduate Medicine, vol.11, no.2, pp.65-70, (2013) 
The Role of Civil Society in Preventing and Countering Sexual Violence in Nigeria

[30] T. Falola, "Violence in Nigeria: The crisis of religious politics and secular ideology," New York, USA: University of Rochester Press, (1998)

[31] E. Feron, "Violence against men: Masculinities and power in the conflict zone," Lanham, USA: Rowman and Littlefield, (2017)

[32] E. B. Freedman, "Redefining rape: Sexual violence in the era of suffrage and segregation," Cambridge, USA: Harvard University Press, (2013)

[33] I. H. Frieze, C. E. Newhill, and R. Fusco, "Dynamics of family and intimate partner violence Geneva," Springer, (2020)

[34] T. A. Gannon and C. Ó Ciardha, "Psychological theories related to sexual violence and abuse," In J.L. Postmus (Ed.), Sexual Violence and Abuse: An Encyclopedia of Prevention, Impacts, and Recovery, Santa Barbara, CA: ABC-CLIO, pp.31-39, (2012)

[35] A. Gentili, "Ethnicity and citizenship in sub-Saharan Africa," In Chabal, P., Engel, U., \& Gentili, E. (Eds.), Theories of Conflict And Approaches to Conflict Prevention, Boston, USA: Brill, pp.35-54, (2005)

[36] L. B. Girshick, "Woman to woman sexual violence: Does she calls it a rape?" Boston, USA: Northeastern University Press, (2002)

[37] L. Goodmark, "Decriminalizing domestic violence: A balanced policy approach to intimate partner violence," California: University of California Press, (2018)

[38] C. Harrington, Politicization of Sexual Violence: From Abolitionism to Peacekeeping, Surrey, UK: Ashgate Publishing, (2010)

[39] A. J. Hattery and E. Smith, "Gender, power, and violence: Responding to sexual and intimate partner violence in society today," Lanham: Rowman and Littlefield, (2019)

[40] S. Hayes, "Sex, love, and abuse: Discourses on domestic violence and sexual assault," New York, USA: Palgrave Macmillan, (2014)

[41] R. Hazelwood and S. G. Michaud, "Dark dreams: A legendary FBI profiler examines homicide and the criminal mind," Boston, USA: St. Martin's Paperback, (2018)

[42] A. Healicon, "The politics of sexual violence: Rape, identity and feminism," New York, USA: Palgrave Macmilla, (2015)

[43] E. A. Heintze, "Global violence: Ethical and political issues," London, UK: Routledge, Taylor, and Francis, (2016)

[44] S. Hischauer, "The securitization of rape: Women, war and sexual violence," New York, USA: Palgrave Macmillan, (2014)

[45] A. O. Ikelegbe, "The state and civil society in Nigeria: Towards a partnership for sustainable development," Benin, Nigeria: Centre for Population and Environmental Development, (2013)

[46] Q. Iroanusi, “At least 3,600 rape cases recorded during lockdown-minister in premium times," Retrieved from https://www.premiumtimesng.com/news/top-news/402783-at-least-3600-rape-cases-recorded-duringlockdown-minister.html on 11-08-2020 at 2:52 pm

[47] A. Isiaka, "Nigeria declares 'state of emergency' on rape and sexual assault," Global Voices, Retrieved from https://globalvoices.org/2020/07/03/nigeria-declares-state-of-emergency-on-rape-and-sexual-assault/ on 11$08-2020$ at $2: 57 \mathrm{pm}$

[48] H. A. Javier and W. G. Herron, "A look at domestic violence through the trauma less: An introduction," In Javier, H.A., \& Herron, W.G. (Eds.), Understanding Domestic Violence: Theories, Challenges, and Remedies, pp.1-20. Lanham: Rowman \& Littlefield, (2018)

[49] E. L. Jeglic and C. Calkins, "Starting the conversation: A shift in paradigm,” In Jeglic E.L. \& Calkins, C. (Eds.), Sexual Violence: Evidence-Based Policy and Prevention, pp.1-10. Geneva, Switzerland: Springer, (2016)

[50] M. Judge, "Blackwashing homophobia: Violence and the politics of sexuality, gender, and race," London, UK: Routledge, Taylor \& Francis, (2018)

[51] L. Kelly, "Surviving sexual violence," Cambridge, UK: Polity Press, (1988) 
[52] F. B. Kemisola and F. E. Olawale, "Rape and sexual violence against the girl-child: Securing the future through good governance in Nigeria," International Journal of Public Administration and Management Research (IJPAMR), vol.4, no.2, pp.13-23, (2017)

[53] N. Lombard and L. McMillan, "Violence against women: Current theory and practice in domestic abuse," Sexual Violence and Exploitation, London, UK: Jessica Kingsley Publishers, (2013)

[54] M. M. I. Margaret-Mary, M. Okoye, and F. F. Alamina, "Sexual violence among female undergraduates in a tertiary institution in port Harcourt: Prevalence, pattern, determinants and health consequences," African Journal of Reproductive Health, vol.18, no.4, pp.79-85, (2014)

[55] M. D. Muluneh, B. Stulz, L. Francis, and K. Ago, "Gender-based violence against women in Sub-Saharan Africa: A systematic review and meta-analysis of cross-sectional studies," International Journal of Environmental Research and Public Health, vol.2, no.1, pp.2-21

[56] D. Mutua, "Nigeria records 717 rape cases in five months-official," In All Africa, Retrieved from https://allafrica.com/stories/202006150851.html on 11-08-2020 at 2:48 pm, (2020)

[57] S. Muwanga, D. Traore, H. Chekir, and A. Tsunga, "The impact of litigation on combating sexual violence and its consequences in Africa," Ndjamena, Chad: International Federation for Human Rights (FIDH), (2016)

[58] N. Orjinmo, “\#WeAreTired: Nigerian women speak out over wave of violence," BBC News, retrieved from https://www.bbc.com/news/world-africa-52889965 on 11-08-2020 at 7:10 pm, (2020)

[59] J. Pottier, P. Hammond, and C. Cramer, "Navigating the terrain and methods and ethics in conflict research," In Cramer, C. Hammond, L. \& Pottier, J. (Eds.), Researching Violence in Africa: Ethical and Methodological Challenge, pp.1-22. Boston, USA: Leiden, (2013)

[60] N. Powell and N. Henry, "Sexual violence in the digital age," New York, USA: Palgrave Macmillan, (2017)

[61] E. P. Raphael, B. O. Ajah, and D. Chukwuemeka, "Eradicating sexual assault in Nigerian university system: The role of investigative journalism," Annals of Journalism and Mass Communication, vol.1, no.1, pp.1-6, (2019)

[62] Relief Web, "Sexual violence: Why the rise?" (2020), Retrieved from https://reliefweb.int/report/nigeria/sexual-violence-why-rise on 11-08-2020 at 7:26 pm

[63] M. L. Salamon, H. K. Anheier, R. List, S. Toepler, and S. W. Sokolowski, Global Civil Society Sector: Dimensions of the Nonprofit Sector. Baltimore, USA: The John Hopkins Centre for Civil Society Studies, (1997)

[64] R. L. Snyder, "No visible bruises: What we don't know about domestic violence can kill us," New York: Bloomsbury Publishing, (2019)

[65] D. Sriskandarajah, "State of civil society report 2016 executive summary.," (2016) CIVICUS, Retrieved from http://civicus.org/images/documents/SOCS2016/summaries/State-of-Civil-Society-Report-2016_ExecSummary.pdf on 11-08-2020 at 2:30 pm

[66] P. Taft and H. Blyth, "Child sexual assault and violence in Nigeria's Kano State," Abuja, Nigeria: The Fund for Peace, (2016)

[67] A. Tar, "The politics of neoliberal democracy in Africa: State and civil society in Nigeria London," UK: I B Tauris Publishers, (2008)

[68] The Cece Yara Foundation "Needs assessment report: On the provision of a child helpline in Lagos," (2020), Retrieved from https://www.ceceyara.org/resources/statistics on 11-08-2020 at 7:13 pm

[69] The World Bank "Sexual violence," Washington, USA: The World Bank Publication, (2019)

[70] J. Tosh, "Perverse psychology: The pathologizing of sexual violence and transgenderism," London, UK: Routledge, Taylor \& Francis, (2015)

[71] E. I. Udogu, "The military, civil society and the issue of democratic governance: Towards Nigeria's fourth republic," Journal of Developing Studies, vol.13, no.2, pp.206-220, (1995)

[72] United States Agency for International Development (USAID), Democracy and Governance Assessment in Nigeria. Washington: USAID Publication, (2006) 
The Role of Civil Society in Preventing and Countering Sexual Violence in Nigeria

[73] UN Nigeria "Nigeria: Prevalence data on different forms of violence against women Washington," USA: United Nations, (2020), Retrieved from https://evaw-global-database.unwomen.org/fr/countries/africa/nigeria on $11-08-2020$ at 7:21 pm

[74] UN Women, "Facts and figures: Ending violence against women. Various forms of violence," Washington, USA: United Nations, (2020), Retrieved from https://www.unwomen.org/en/what-we-do/ending-violenceagainst-women/facts-and-figures on 11-08-2020 at 7:15 pm

[75] UN Women, "Violence against women and girls: The shadow pandemic," Washington, USA: United Nations, (2020), https://www.unwomen.org/en/news/stories/2020/4/statement-ed-phumzile-violence-against-womenduring-pandemic on 11-08-2020 at 7:31 pm

[76] M. Utsaha, "The rule of law: The role of civil society in Nigeria," Being a Text of Presentation at a Round Table Organized by Konrad Adenauer Stiftung Tuesday, June 10, 2014, Maitama, Abuja, FCT, (2014)

[77] Women at Risk International Foundation, "Rape stats in Nigeria," (2020), Retrieved from https://warifng.org/rape-stats-in-nigeria/ on 11-08-2020 at 7:24 pm

[78] World Bank Group, "Gender-based violence: An analysis of the implications for Nigeria for women project," Washington, USA: The World Bank, (2019)

[79] World Health Organization, "Preventing intimate partner and sexual violence against women: Taking action and generating evidence," Geneva, Switzerland: World Health Organization, (2010)

[80] World Health Organization, "Civil society declaration on sexual violence," Washington, USA.WHO, (2014)

[81] S. Zizek, "Violence,” London, USA: Profile Books, (2009) 